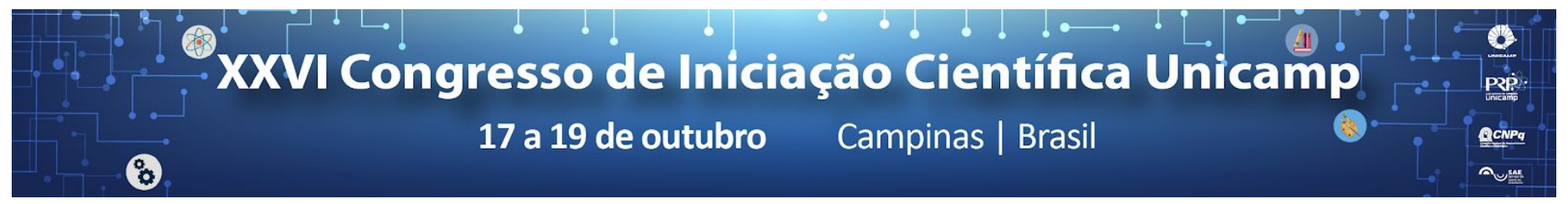

doi:10.20396/revpibic262018625

\title{
Participação de um aluno surdo em escola de ensino alternativo
}

\section{Isabela Palanch M. Silva*, Aryane Santos Nogueira}

\section{Resumo}

O objetivo desta pesquisa é focalizar e tematizar a inserção e participação do aluno surdo no ambiente escolar não tradicional. Baseada no contexto atual das políticas adotadas para a inclusão de surdos na sala de ensino regular e, partindo do pressuposto de que este modelo não é satisfatório, a busca é por lançar luz sobre os modos como a participação desse aluno se efetiva na escola de ensino alternativo. Sendo assim, o contexto a ser analisado é o aluno surdo dentro de sua comunidade escolar.

\section{Palavras-chave:}

Aluno surdo, escola. ensino alternativo.

\section{Introdução}

Uma sociedade organizada para a maioria ouvinte cria barreiras para as pessoas surdas que, já há muito tempo, têm que lidar com a imposição de um padrão de "normalidade" que percebe na diferença surda um problema a ser resolvido (SKLIAR, 1998). A dificuldade na inclusão de alunos surdos no sistema educacional é uma dessas barreiras.

Assumindo a existência de uma carência de pesquisas sobre a educação de surdos e as pedagogias alternativas - uma pedagogia que favorece as diferenças, o trabalho coletivo e a participação do aluno -, buscou-se observar situações do contexto escolar, dentro e fora da sala de aula, que demonstrassem a existência de estratégias próprias desse modelo favoráveis à educação do aluno surdo.

O projeto foi submetido ao comitê de ética e recebeu aprovação sob o número CAAE: 81098317.0.0000.8142.

\section{Resultados e Discussão}

Os alunos surdos quando inseridos na escola regular, muitas vezes encontram-se presentes fisicamente, mas não participando efetivamente das atividades desenvolvidas em contexto que, em tese, é inclusivo (GÓES \& TARTUCI, 2002; LACERDA, 2006). Na escola de ensino alternativo na qual as observações desta pesquisa foram realizadas, localizada no interior do estado de São Paulo, uma das situações observadas, permite tecermos algumas reflexões sobre a situação do único aluno surdo inserido no contexto: a elaboração de um trabalho para uma feira de encerramento do semestre. Tal atividade envolveu a escolha de um tema que seria desenvolvido para ser apresentado na feira que contaria com a participação de todos os alunos da escola. A pouca autonomia do aluno surdo expressou-se logo de início, quando o tema a ser desenvolvido lhe foi sugerido e não de escolha própria. Foi interessante observar que a sugestão de tema - elaboração de um jogo de perguntas e respostas sobre o aparelho auditivo (Figura 1) - envolveu um aspecto diretamente relacionado à realidade vivenciada pelo aluno, uma vez que ele próprio é usuário de aparelhos de audição. No entanto, não se cogitou encontrar junto ao aluno um tema que ele gostaria de desenvolver, já que o que proposto poderia não ser de interesse.

Figura 1. Jogo desenvolvido pelo aluno

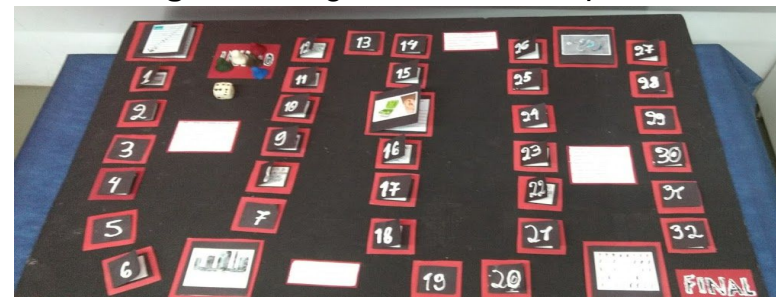

Fonte: dados coletados pela autora.

O modo como se constitui o envolvimento do aluno nessa primeira etapa do projeto pode ter refletido diretamente em sua atuação no momento de apresentação de seu trabalho na feira da escola. Nessa segunda etapa, o aluno surdo demonstrou dificuldade para explicar o propósito e funcionamento do seu jogo. Consideramos, assim, que a participação do aluno surdo não foi efetiva na situação observada, refletindo um contexto escolar que pode não ser, de fato, inclusivo.

\section{Conclusões}

A pesquisa ainda se encontra em andamento, no entanto, a análise parcial permite considerarmos que, ainda que o modelo alternativo tenha como característica uma pedagogia que favoreça a participação e a autonomia do aluno, na situação observada as especificidades do aluno surdo não foram contempladas.

GÓES, M.C.R.; TARTUCI, D. Alunos surdos na escola regular: as experiências de letramento e os rituais da sala de aula. In: LODI, A.C.B. et al (Org.). Letramento e minorias. Porto Alegre: Mediação, 2002.p.110-119.

LACERDA, C.B.F. A inclusão escolar de alunos surdos: o que dizem alunos, professores e intérpretes sobre esta experiência. Cad. Cedes, vol. 26, n. 69, p. 163-184, 2006.

SKLIAR, C. A surdez: um olhar sobre as diferenças. Porto Alegre: Mediação, 1998. 